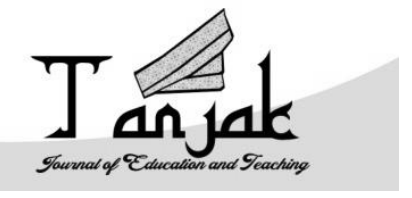

Tanjak: Journal of Education and Teaching
ISSN 2716-4098 (P) 2720-8966 (O)
Volume 1 Nomor 1, 2020

\title{
Peranan Masjid Dalam Pendidkan Islam Masyarakat Pulau Penyengat
}

\author{
Erlina gusnita ${ }^{1 *}$, M. teddi rahardi ${ }^{2}$ \\ Ellenellyn@gmail.com \\ 1,2 STAIN Sultan Abdurrahman, Bintan, Kepulauan Riau, 29135, Indonesia
}

DOI: https://doi.org/10.35961/tanjak. v1i1.63

\begin{abstract}
Abstrak
Penelitian ini dilatarbelakangi oleh revitalisasi masjid sebagai lembaga pendidikan Islam sangat penting untuk meningkatkan kualitas pendidikan Islam dan menghadapi isu yang multidimensional. Masjid Sultan Riau Penyengat merupakan masjid bersejarah di Pulau Penyengat Kota Tanjungpinang Provinsi Kepulauan Riau. Masjid tersebut terletak di tempat yang strategis sehingga mudah diakses oleh kaum muslimin. Masjid tersebut biasa digunakan sebagai lembaga pendidikan Islam mulai dari sebagai tempat ibadah, dakwah maupun sebagai tempat belajar yang sifatnya nonformal. Peran masjid tersebut nampaknya didukung dengan adanya perguruan tinggi, pemerintah daerah dan masyarakat setempat. Fokus penelitiannya adalah Bagaimana peranan Masjid Sultan Riau Penyengat Kota Tanjungpinang Provinsi Kepulauan Riau sebagai lembaga dakwah. Bagaimana peranan Masjid Sultan Riau Penyengat Kota Tanjungpinang Provinsi Kepulauan Riau sebagai lembaga ibadah. Bagaimana peranan Masjid Sultan Riau Penyengat Kota Tanjungpinang Provinsi Kepulauan Riau sebagai lembaga kemasyarakatan. Tujuan penelitiannya adalah untuk mengetahui peranan Masjid Sultan Riau Penyengat Kota Tanjungpinang Provinsi Kepulauan Riau sebagai lembaga dakwah. Untuk mengetahui peranan Masjid Sultan Riau Penyengat Kota Tanjungpinang Provinsi Kepulauan Riau sebagai lembaga ibadah. Untuk mengetahui peranan Masjid Sultan Riau Penyengat Kota Tanjungpinang Provinsi Kepulauan Riau sebagai lembaga kemasyarakatan

Metode penelitian, penelitian ini bersifat deskriptif kualitatif, lokasinya di Masjid Sultan Riau Penyengat, metode pengumpulan data adalah observasi, interview, dan dokumentasi. Analisis data dengan reduksi data. Pengecekan keabsahan memakai triangulasi, pembahasan sejawat, dan perpanjangan keikutsertaan.

Hasil penelitian: Peran utama masjid, terutama masjid Sultan Riau Penyengat adalah sebagai lembaga atau tempat ibadah. Sebagaimana data yang masuk, tujuan pengunjung yang datang ke masjid semuanya adalah untuk menjalankan ibadah, baik
\end{abstract}


ibadah fardhu maupun ibadah sunnah. Bahkan tidak ada sebuah masjid yang sengaja dibangun, namun tidak berfungsi sebagai tempat ibadah ini. Semua umat Islam sepakat dengan fungsi masjid yang ini, namun kadang-kadang berbeda mengenai fungsi yang lainnya. Masjid al-Munawar ini juga berperan sebagai lembaga dakwah, terbukti dengan adanya kegiatan-kegiatan untuk mensyiarkan Islam dan membangkitkan semangat beribadah, yang berupa kegiatan pengajian akbar, tilawah al-Qur'an dan sebagainya, walaupun tidak berfungsi sebagai masjid yang berpersantren. Peran masjid Sultan Riau Penyengat sebagai lembaga kemasyarakatan ada yang sudah termasuk ke dalam peran masjid sebagai lembaga ibadah, yaitu ketika shalat berjamaah. Ada juga yang melalui kegiatan keagamaan tertentu, seperti halnya tilawah al-Qur'an, pengajian, dan lain-lain, masyarakat semua berperan aktif dalam hal itu.

Kata kunci: Masjid; Pendidikan; Islam.

\section{Pendahuluan}

Pendidikan Islam di Indonesia merupakan warisan peradaban Islam dan sekaligus aset bagi pembangunan pendidikan nasional. Sebagai warisan, ia merupakan amanat sejarah untuk dipelihara dan dikembangkan oleh umat Islam dari masa ke masa. Sedangkan sebagai aset, pendidikan Islam yang tersebar di berbagai wilayah ini membuka kesempatan bagi bangsa Indonesia untuk menata dan mengelolanya, sesuai dengan sistem pendidikan nasional. ${ }^{1}$

Upaya pengelolaan maupun pengembangan lembaga pendidikan Islam merupakan keniscayaan dan beban kolektif bagi para penentu kebijakan pendidikan Islam. Mereka memiliki keharusan untuk merumuskan strategi dan mempraktikkannya guna memajukan pendidikan Islam. Mereka juga harus melakukan revitalisasi terhadap lembaga-lembaga yang mempunyai eksistensi yang rendah dan kurang diminati oleh masyarakat sebagai lembaga pendidikan Islam.

Keadaan lembaga Pendidikan Islam di Indonesia terutama dalam bentuk masjid telah cukup tua karena mengiringi keberadaan para penyebar Islam. Lembaga tersebut mengalami penambahanpenambahan secara kuantitatif dan tampaknya penambahan secara kuantitatif tersebut merebak di seluruh Indonesia. Jumlah lembaga-lembaga itu senantiasa bertambah dari tahun ke tahun dan tersebar di seluruh Indonesia. Namun, secara kualitatif masih menghadapi berbagai problema yang serius dan sedang berusaha untuk diatasi baik problem yang bersifat internal maupun eksternal.

Di samping itu, perkembangan ilmu pengetahuan dan teknologi serta budaya masyarakat menimbulkan tuntutan yang makin tinggi terhadap standar pendidikan. Apalagi ketika disadari bahwa pendidikan sebagai faktor penentu terhadap kemajuan peradaban dan kebudayaan bangsa. Sehingga terasa sekali adanya kelemahan-kelemahan yang ada pada pendidikan Islam untuk segera dipecahkan dan diatasi bersama-sama. ${ }^{2}$

Secara umum, lembaga pendidikan Islam masih tertinggal. Kita harus menerima kenyataan yang pahit bahwa posisi pendidikan Islam di Indonesia menempati 'kelas ekonomi' dengan tetap memiliki komitmen menjadikannya sebagai bahan pertimbangan dalam membangun kembali di masa depan. ${ }^{3} \mathrm{Hal}$ tersebut terlihat dari nasib lembaga-lembaga pendidikan Islam itu yang masih tidak terawat dengan baik.

\footnotetext{
${ }^{1}$ Husni Rahim, Arah Baru Pendidikan Islam di Indonesia, (Jakarta: PT. Logos Wacana Ilmu, 2001), hal. 3.

2 Mujamil Qomar, Manajemen Pendidikan Islam: Strategi Baru Pengelolaan Lembaga Pendidikan Islam, Jakarta: Erlangga, 2008), hal. 35.

${ }^{3}$ Mujamil Qomar, "Perencanaan: Suatu Proses yang Terabaikan dalam Sistem Pendidikan Islam", Majalah Tarbiyah Tulungagung IAIN Sunan Ampel, no.9, Tahun V, 1993, hal.29
} 
Masjid sebagai lembaga pendidikan Islam yang tertua yang sudah ada sejak zaman Nabi Muhammad perlu dijaga dan dipelihara eksistensinya sampai sekarang. Kalau dilihat dari sejarahnya, kaum muslimin telah memanfaatkan masjid untuk tempat beribadah, lembaga pendidikan dan pengetahuan Islam. ${ }^{4}$ Jadi pada zaman dahulu masjid adalah tempat yang digunakan sebagai pusat kajian Islam, bahkan merupakan tempat memutuskan hukum Islam.

Namun, pada dekade akhir-akhir ini masjid tidak lagi berperan penting dalam pendidikan Islam. Pendidikan Islam seperti juga pendidikan lainnya akan menghadapi gejala-gejala dan tantangan yang multidimensional. Husni Rahim menyatakan, "Masa depan pendidikan Islam dipengaruhi tiga isu besar: globalisasi, demokratisasi dan liberalisasi Islam" ${ }^{5}$ Globalisasi juga mempengaruhi sistem pendidikan. Penetrasi budaya global terhadap kehidupan masyarakat Indonesia akan direspon secara berbeda-beda oleh kalangan pendidikan: permisif, defensif, dan transformatif. Tuntutan demokratisasi pada akhirnya mengarah pada sistem pengelolaan pendidikan; tuntutan pengelolaan pendidikan yang lebih otonom dan beragam, tuntutan partisipasi masyarakat khususnya dalam pengawasan mutu pendidikan semakin meningkat, tuntutan pengelolaan pendidikan yang transparan dan bertanggungjawab, dan tuntutan menggeser paradigma pendidikan sehingga menekankan pada peran siswa secara aktif.

Selanjutnya, isu liberalisasi Islam juga akan mempengaruhi pendidikan Islam, baik dalam perspektif yang ekstrim maupun perspektif yang moderat. Dalam perspektif yang ekstrim, liberalisasi Islam berarti mengabaikan sama sekali teks-teks suci ketika membahas isu-isu yang memang tidak dijelaskan secara ekaplisitt di dalamnya. Sedangkan perspektif yang moderat menyadari perlunya penafsiran yang bebas terhadap teks-teks suci sejauh konsisten dengan nilai dasar yang dikandungnya, sehingga isu baru apa pun yang berkembang dewasa ini pada dasarnya memiliki relevansi dengan esensi ajaran agama. ${ }^{6}$

Selain pengaruh dari isu-isu yang bersifat mendunia, pendidikan Islam harus juga tanggap terhadap problema-problema nasional mengingat bahwa pendidikan Islam sebagai aset pembangunan pendidikan nasional. Dalam posisi seperti ini, merupakan keharusan moral bagi pendidikan Islam untuk memberikan kontribusi dalam memecahkan problematika yang mendera bangsa Indonesia. Fadjar kembali menyarankan bahwa pengembangan pendidikan Islam ke depan secara realistik harus disinkronkan dengan kebijakan pendidikan national guna membebaskan bangsa dari himpitan berbagai persoalan. ${ }^{7}$ Maka dari itu, peran dari lembaga pendidikan perlu ditingkatkan kembali. Salah satunya adalah mengadakan revitalisasi peran masjid sebagai lembaga alternatif dalam pendidikan Islam. Di samping itu, pendidikan Islam juga harus memiliki orientasi visioner ke depan yang multidimensional agar mampu menanggapi dan merespon isu-isu yang berkembang, baik dalam skala global maupun nasional.

Masjid Sultan Riau Pulau Penyengat merupakan masjid yang penuh sejarah yang merupakan suatu aset terbesar yang ada di kota Tanjungpinang Provinsi Kepulauan Riau. Masjid tersebut terletak di Sebuah Pulau Yaitu di Pulau Penyengat tempat yang strategis sehingga mudah diakses oleh kaum muslimin dengan menggunakan perahu Boat atau disebut dengan Pompong. Masjid tersebut biasa

${ }_{4}^{4}$ Mohd Athiyah al-Abrasy, Dasar-Dasar Pokok Pendidikan Islam, terj. Bustami A.Ghani dan Djohar Bahry, (Jakarta: Bulan Bintang, 1970), hal. 58.

${ }^{5}$ Rahim, Arah Baru..., hal. 14.

${ }^{6}$ Ibid., hal. 14-16.

7 A. Malik Fadjar, "Pendahuluan: Strategi Pengembangan Pendidikan Islam Dalam Era Globalisasi", dalam M. Zainuddin dan Muhammad In'am Esha (eds), Horison Baru Pengembangan Pendidikan Islam Upaya Merespon Dinamika Masyarakat Global, (Yokyakarta: Aditya Media Yokyakarta Bekerjasama dengan UIN Press, 2004), hal. xxi-xxii 
digunakan sebagai lembaga ke-Islaman mulai dari sebagai tempat ibadah, dakwah maupun sebagai tempat belajar yang sifatnya nonformal. Peran masjid tersebut nampaknya didukung dengan adanya perguruan tinggi, sekolah-sekolah Islam lainnya yang berada di Provinsi tersebut. Mahasiswa dan siswasiswa dari perguruan tinggi dan sekolah-sekolah tersebut menambah semarak peran masjid sebagai lembaga pendidikan Islam dan membuat seolah-seolah masjid kembali memainkan fungsinya dalam pendidikan Islam.

Berdasarkan uraian di atas, maka revitalisasi masjid sebagai lembaga ke- Islaman sangat penting untuk meningkatkan kualitas pendidikan Islam dalam menghadapi isu yang multidimensional. Berangkat dari hal itulah maka peneliti tertarik untuk mengadakan penelitian yang peneliti tuangkan dalam skripsi yang berjudul "Peran Masjid Dalam Meningkatkan Pendidikan Islam Masyarakat Pulau Penyengat (studi kasus Masjid Raya Sultan Riau Pulau Penyengat)".

Fokus penelitian yang akan peneliti ajukan di sini berdasarkan latar belakang masalah yang sudah peneliti uraikan di atas adalah sebagai berikut:

1. Bagaimana peranan Masjid Raya Sultan Riau Pulau Penyengat sebagai lembaga Pendidikan?

2. Bagaimana peranan Masjid Raya Sultan Riau Pulau Penyengat sebagai lembaga ibadah?

3. Bagaimana peranan Masjid Raya Sultan Riau Pulau Penyengat sebagai lembaga kemasyarakatan?

Berdasarkan fokus penelitian tersebut di atas, maka tujuan penelitian yang dimaksud adalah sebagai berikut:

1. Untuk mengetahui peranan Masjid Raya Sultan Riau Pulau Penyengat sebagai lembaga dakwah.

2. Untuk mengetahui peranan Masjid Raya Sultan Riau Pulau Penyengat sebagai lembaga ibadah.

3. Untuk mengetahui peranan Masjid Raya Sultan Riau Pulau Penyengat sebagai lembaga kemasyarakatan.

\section{Metode Penelitian}

Jika dilihat dari lokasi penelitiannya, maka jenis penelitian ini merupakan jenis penelitian lapangan (field research). Menurut Suryasubrata, penelitian lapangan bertujuan "mempelajari secara intensif latar belakang, keadaan sekarang, dan interaksi lingkungan suatu unit sosial; individu, kelompok, lembaga atau masyarakat". ${ }^{8}$ Sementara itu, jika dilihat dari sifat datanya, karena data yang dikumpulkan bersifat deskriptif atau kata-kata, maka penelitian ini termasuk dalam kategori penelitian kualitatif. Bogdan dan Taylor mengemukakan, penelitian kualitatif adalah prosedur "penelitian yang menghasilkan data deskriptif, berupa kata-kata tertulis atau lisan dari orang-orang dan perilaku yang dapat diamati." 9 Sementara itu, Miles \& Huberman, sebagaimana dikutip Tanzeh dan Suyitno, mengemukakan bahwa penelitian kualitatif merupakan penelitian yang bertitik tolak dari realitas dengan asumsi pokok bahwa tingkah laku manusia mempunyai makna bagi pelakunya dalam konteks tertentu. ${ }^{10}$ Sejalan dengan definisi tersebut, Kirk dan Miller, sebagaimana dikutip Moleong, mendefinisikan bahwa penelitian kualitatif adalah tradisi tertentu dalam ilmu pengetahuan sosial yang secara fundamental bergantung dari pengamatan pada manusia baik dalam kawasannya maupun dalam peristilahannya. ${ }^{11}$

${ }^{8}$ Sumadi Suryasubrata, Metodologi Penelitian, (Jakarta: Raja Grafindo Persada, 1998), hal. 22.

9Steven J. Taylor dan Robert C Bogdan, Introduction to Qualitative Research Methods: The Search for Meaning, (New York: Wiley and Sons Inc, 1984), hal. 5.

${ }^{10}$ Ahmad Tanzeh dan Suyitno, Dasar-Dasar Penelitian, (Surabaya: eLKAF, 2006), hal. 113.

${ }^{11}$ Lexy J.Moleong, Metodologi Penelitian Kualitatif, (Bandung: PT Remaja Rosdakarya, 2007), hal. 4. 
Peneliti menerapkan pendekatan kualitatif ini berdasarkan beberapa pertimbangan: pertama, "menyesuaikan metode kualitatif lebih mudah apabila berhadapan dengan kenyataan ganda". ${ }^{12}$ Kedua, "metode ini menyajikan secara langsung hakikat hubungan antara peneliti dan responden." 13 Dengan demikian peneliti ingin mengenal lebih dekat dan menjalin hubungan yang baik dengan subyek dan dapat mempelajari sesuatu yang belum diketahui sama sekali, serta dapat mempermudah dalam menyajikan data deskriptif. Ketiga, "metode ini lebih peka dan lebih dapat menyesuaikan diri dengan banyak penajaman pengaruh bersama dan terhadap pola-pola nilai yang dihadapi”. ${ }^{14}$ Dengan demikian peneliti berusaha memahami keadaan subyek dan senantiasa berhati-hati dalam penggalian informasi agar subyek tidak merasa terbebani.

Selanjutnya, jika dilihat dari jenis data yang dikumpulkan, maka penelitian ini adalah penelitian deskriptif, yaitu penelitian yang berusaha menggambarkan apa adanya tentang suatu variabel, gejala atau keadaan. ${ }^{15}$ Dalam penelitian deskriptif, terdapat 4 tipe, yaitu survei, studi kasus, penelitian korelasional dan penelitian kausal. Adapun penelitian yang penulis lakukan ini adalah penelitian studi kasus, yaitu uraian dan penjelasan komprehensif mengenai berbagai aspek individu, suatu kelompok, suatu organisasi (komunitas), suatu program atau suatu situasi sosial. ${ }^{16}$

\section{Hasil dan Pembahasan}

Dari pemaparan data tersebut dapat diperoleh gambaran umum dalam bentuk analisis deskriptif yang merupakan temuan penelitian. Dari penelitian yang dilakukan oleh peneliti di Masjid Raya Sultan Riau menemukan hal-hal yang berkaitan dengan fokus penelitian sebagai berikut:

1. Masjid Raya Sultan Riau berperan sebagai lembaga ibadah dengan bukti banyak pengunjung yang datang untuk melaksanakan shalat, diadakan berbagai kegiatan-kegiatan keagamaan sebagai penunjang ibadah harian dan penguatan keimanan.

2. Masjid Raya Sultan Riau ini juga berperan sebagai lembaga dakwah, terbukti dengan adanya kegiatan-kegiatan untuk mensyiarkan Islam dan membangkitkan semangat beribadah, yang berupa kegiatan pengajian akbar, tilawah al-Qur'an dan sebagainya

3. Peran masjid Raya Sultan Riau sebagai lembaga kemasyarakatan ada yang sudah include ke dalam peran masjid sebagai lembaga ibadah, yaitu ketika shalat berjamaah. Ada juga yang melalui kegiatan keagamaan tertentu, seperti halnya tilawah al-Qur'an, pengajian, dan lain-lain. Dimana masyarakat semua berperan aktif dalam hal itu.

\section{Masjid sebagai Lembaga Ibadah}

Masjid Raya Sultan Riau berperan sebagai lembaga ibadah dengan bukti banyak pengunjung yang datang untuk melaksanakan shalat, diadakan berbagai kegiatan-kegiatan keagamaan sebagai penunjang ibadah harian dan penguatan keimanan. Peran masjid Raya Sultan Riau sebagai lembaga ini dinyatakan oleh seluruh responden yang peneliti wawancarai, bahkan peneliti ikut dan menyaksikan secara langsung ibadah shalat yang dilaksanakan.

\footnotetext{
12 Ibid., hal. 5.

${ }_{13}$ Ibid.

${ }^{14}$ Ibid.

${ }^{15}$ Suharsimi Arikunto, Manajemen Penelitian, (Jakarta: Rineka Cipta, 2003), hal. 310.

${ }^{16}$ Dedy Mulyana, Metodologi Penelitian Kualitatif: Paradigma Baru Ilmu Komunikasi dan Ilmu Sosial Lainnya, (Bandung: PT Remaja Rosdakarya, 2003), hal. 201.
} 
Peran masjid sebagai lembaga ibadah disepakati oleh semua ahli dan ulama, bahkan peran ini sesuai dengan makna kata masjid tersebut. Perkataan masjid berasal dari kata bahasa Arab. Masjid berasal dari pokok sujudan, dengan fi'il madli sajada yang berarti tempat sujud atau tempat sembahyang, dan karena berupa isim makan, maka diberi awalan "ma" yang kemudian berubah kata menjadi masjidu.

Maksud peran masjid sebagai lembaga ibadah di sini adalah ibadah yang tidak hanya dalam artis sempit, namun juga dalam arti luas. Hal itu dikarenakan pengertian dan fungsi masjid mencakup berbagai aspek kehidupan umat Islam. Oleh karena itu pula pengertian dan fungsi masjid juga dapat mencakup proses pembentukan budaya Islam dimana di dalamnya tercakup pula proses pendidikan. Fungsi utama masjid sesuai dengan namanya yang merupakan isim makan dari sajada adalah tempat melaksanakan sujud atau shalat. Setiap masjid harus mempunyai mibrab yang mengarah ke kiblat, karena setiap umat Islam dalam melaksanakan shalat harus mengarah kiblat. Fungsi ini merupakan fungsi yang utama dari sebuah masjid, tidak berbeda antara masjid besar maupun masjid kecil bahkan masjid yang diberi arsitektur yang tinggi. Bahkan tidak ada sebuah masjid yang sengaja dibangun, namun tidak berfungsi sebagai tempat melaksanakan shalat. Semua umat Islam sepakat dengan fungsi masjid yang ini, namun kadang-kadang berbeda mengenai fungsi yang lainnya.

Berdasarkan fungsi utama tersebut, maka dapat dikatakan peran utama masjid, terutama masjid Raya Sultan Riau adalah sebagai lembaga atau tempat ibadah. Karena sebagaimana data yang masuk, tujuan pengunjung yang datang ke masjid semuanya adalah untuk menjalankan ibadah, baik ibadah fardhu maupun ibadah sunnah, baik ibadah mabdhah maupun ibadah ghairu mahdhah.

\section{Masjid sebagai Lembaga Dakwah}

Masjid Raya Sultan Riau ini juga berperan sebagai lembaga dakwah, terbukti dengan adanya kegiatan-kegiatan untuk mensyiarkan Islam dan membangkitkan semangat beribadah, yang berupa kegiatan pengajian akbar, tilawah al-Qur'an dan sebagainya. Hal ini sebagaimana dikemukakan oleh ta'mir masjid Raya Sultan Riau, remas, maupun beberapa pengunjung yang sempat peneliti interview.

Peranan masjid yang berikutnya adalah sebagai lembaga dakwah. Karena masjid sudah berperan sebagai lembaga ibadah maka secara otomatis masjid berperan sebagai lembaga dakwah. Masjid biasa digunakan sebagai tempat pengajian-pengajian, baik yang berupa kultum ataupun pengajian akbar. Selain itu masjid juga digunakan sebagai tempat pendidikan Islam, misalnya adanya pengajian kitab kuning di serambi masjid. Hal ini kebanyakan dilakukan oleh masjid yang terdapat pesantren di dekatnya.

Bahkan fenomena terbaru yang muncul akhir-akhir ini adalah pengajian kitab tidak dilakukan pada masjid yang terdapat pesantren di dekatnya, namun juga di masjid jami'. Pengajian kitab yang dilakukan di masjid Jami' ini biasanya didengarkan oleh orang-orang yang sudah berumah tangga atau masyarakat umum. Jadi penekanan pengajian di sini adalah pendidikan kepada masyarakat agar mereka mengerti tentang ajaran agama secara lebih mendalam.

Salah satu fungsi masjid adalah mencerdaskan umat dan memberikan orientasi dakwah. Pengajian-pengajian dan kuliah-kuliah yang dilakukan secara teratur setiap hari atau dilakukan secara rutin berkenaan dengan acara tertentu, merupakan salah satu fungsi masjid sebagai pusat cahaya dan petunjuk masyarakat yang ada disekitarnya.

Keberadaan masjid erat kaitannya dengan pendidikan dan dakwah Islam. Timbulnya madrasah dan pesantren sebagai lembaga pendidikan, misalnya, berasal dari masjid. Perkembangan ini berlanjut 
dari pendidikan pesantren hingga universitas. Sejarah mencatat bahwa pada masa Kekhalifahan Barat (Abd. Ar-Rahman III) tahun 912-961 M dunia Islam menempatkan Universitas Cordova (Spanyol) di dalam Masjid Cordova dengan memiliki lima fakultas, yaitu astronomi, ilmu ukur, kedokteran, ilmu ketuhanan, dan ilmu hukum. Mahasiswa yang mengikuti perkuliahan tersebut berasal dari seluruh penjuru dunia, baik muslim maupun non-muslim. Selain itu, sebagian ruangan masjid Al-Azhar, Mesir, yang dibangun pada tahun $971 \mathrm{M}$ juga dijadikan tempat mengkaji Islam dan pada tahun $1911 \mathrm{M}$ diresmikan oleh pemerintah Mesir sebagai Universitas Agama Islam.

Abdurrahman Mas'ud, sebagaimana dikutip Hamim, menyatakan bahwa bagi komunitas muslim, masjid tentu bukan saja sebagai pusat ibadah, tetapi juga sebagai ajangpendidikan mengingat lembaga pendidikan pesantren pada masa awal ini belum menemukan bentuknya yang final. Masjid dan pesantren sesungguhnya sebagai center of excellence (pusat peradaban) yang saling mendukung dan melengkapi dalam membentuk kepribadian muslim. Sesungguhnya pula dakwah dan pendidikan tidak dapat dipisahkan dari sejarah dan ajaran dasar Islam. ${ }^{17}$

Sebagian fungsi masjid pada masyarakat Melayu yang diantaranya yaitu masjid merupakan pusat komunitas dan berperan sebagai lokus kegiatan ibadah dan pengajaran keagamaan awal. Di masjidlah anak-anak pertama kali dikenalkan dengan unsur-unsur ibadah tradisi santri. Mulai lima atau enam tahun, mereka diajarkan cara melaksanakan shalat, membaca teks Arab dan melantunkan Al-Qur'an. Ada juga pelajaran tentang dasar-dasar teologi dan hukum. Ini disebut pengajian dan umumnya mengambil bentuk ceramah-ceramah yang disampaikan oleh santri senior.

Di daerah urban, pengajian ini sering diisi oleh kiai atau ulama pembaharu di luar kampung. Masjid juga menjadi tempat kegiatan ibadah tahunan yang bersifat umum. Sepanjang bulan Ramadhan masjid digunakan untuk ibadah shalat tarawih dan pembacaan Al-Qur'an. Makanan disediakan oleh keluarga kaya di komunitas tersebut. Praktek ini tidak umum di kalangan Islam Timur Tengah. Masjid lokal juga menjadi tempat penyelenggaraan Idhul Fitri atau lebaran akhir Ramadhan, lebaran kurban yang diadakan pada waktu haji, dan - terutama dikelola oleh kalangan tradisionalis - perayaan Maulud, memperingati kelahiran Nabi.

Sehubungan dengan hal di atas, Zamakhsari Dhofier juga mengatakan bahwa, "masjid merupakan elemen tak terpisahkan dengan pesantren dan dianggap sebagai tempat paling tepat untuk mendidik para santri, terutama dalam praktek sembahyang lima waktu, khutbah dan sembahyang Jum'at, dan pengajaran kitab-kitab klasik." 18 Jadi walaupun tidak berfungsi sebagai masjid yang berpersantren, masjid Raya Sultan Riau juga berperan sebagai lembaga dakwah, terbukti dengan berbagai kegiatan keagamaan yang diadakan yang bertujuan untuk berdakwah dan mensyiarkan agama Islam.

\section{Masjid sebagai Lembaga Kemasyarakatan}

Peran masjid Raya Sultan Riau sebagai lembaga kemasyarakatan ada yang sudah include ke dalam peran masjid sebagai lembaga ibadah, yaitu ketika shalat berjamaah. Ada juga yang melalui kegiatan keagamaan tertentu, seperti halnya tilawah al-Qur'an, pengajian, dan lain-lain. Dimana masyarakat semua berperan aktif dalam hal itu. Hal tersebut sebagaimana dikatakan Tintus dan Lutfiah.

17 Toha Hamim, Naif: Masjid Jadi Pusat pendidikan, (Gerbang Edisi 06, No. 03, Pebruari-April 2000), hal. 27.

18 Zamakhsari Dhofier, Tradisi Pesantren: Studi tentang Pandangan Hidup Kyai, (Jakarta: LP3ES, Cetakan VI, 1994), hal.

19. 
Peran masjid sebagai lembaga kemasyarakatan sangat besar, bukan hanya sebagai lembaga ibadah saja. Hal ini dikarenakan dalam masjid, kaum muslimin mendengarkan pengajian dan pengetahuan berguna bagi kehidupan mereka sehari-hari, berkenaan dengan kehidupan dan pencaharian rezeki atau hubungan dengan masyarakat. Pengunjung mesjid bertemu muka setiap saat, sehingga dapat kenal-mengenal dari dekat, mengetahui keadaan masing-masing serta berbicara langsung dari hati ke hati dalam berbagai persoalan. Peristiwa yang terjadi pada diri anggota jama'ah mesjid, suka dan duka, dapat diketahui dengan cepat dan bisa dilakukan dengan tindakan segera secara bersama.

Bagi umat Islam, masjid sebenarnya merupakan pusat segala pusat kegiatan. Masjid bukan hanya sebagai pusat ibadah khusus seperti shalat dan i'tikaf tetapi merupakan pusat kebudayaan/mu'amalat tempat di mana lahir kebudayaan Islam yang demikian kaya dan berkah. Keadaan ini sudah terbukti mulai dari zaman Rasulullah sampai kemajuan politik dan gerakan Islam saat ini. Masjid juga berperan sebagai lembaga sosial, tempat penduduk bisa saling jumpa, saling berkenalan satu sama lain, mendekatkan hati, berjabat tangan, memperkuat ikatan persaudaraan, saling bertanya tentang kondisi masing-masing, khususnya apabila salah seorang diantara mereka ada yang mengikuti shalat Jum'at. Apabila ia sakit akan dijenguk, jika ia sibuk ia diberitahukan, dan apabila lupa diingatkan.

Hal ini dapat dilihat dari adanya shalat berjamaah. Dengan adanya shalat berjamaah yang dilakukan di masjid, maka masjid juga merupakan tempat yang menciptakan keakraban dan kebersamaan. Atau bahkan dalam kegiatan tertentu yang ada di dalam masjid dilakukan secara bersamasama sebab mustahil apabila terus-menerus seseorang tersebut melakukan kegiatan secara sendirian. Bahkan lebih dalam lagi, masjid bisa menjadi peredam dari sebuah konflik yang terjadi dalam sebuah masyarakat apabila masyarakat yang mengalami konflik tersebut mau melaksanakan shalat berjamaah secara rutin.

Logikanya orang yang datang untuk shalat berjama'ah itu semua sama tidak ada yang diperlakukan istimewa, baik itu pejabat, bupati, maupun presiden. Satu yang membedakan diantara mereka di hadapan Allah hanyalah tingkat ketaqwaannya. Maka di situlah terjalin keakraban yang semula sempat malu atau yang lain, yang pada mulanya jarang bertemu menjadi bertemu. Di situlah masjid dapat menciptakan keakraban dan kebersamaan di kalangan umat Islam, sehingga masjid dapat dikatakan berperan sebagai lembaga kemasyarakatan.

\section{Kesimpulan}

Dari pembahasan di atas, dapat ditarik kesimpulan sebagai berikut:

1. Peran utama masjid, terutama masjid Sultan Riau Penyengat adalah sebagai lembaga atau tempat ibadah. Sebagaimana data yang masuk, tujuan pengunjung yang datang ke masjid semuanya adalah untuk menjalankan ibadah, baik ibadah fardhu maupun ibadah sunnah. Bahkan tidak ada sebuah masjid yang sengaja dibangun, namun tidak berfungsi sebagai tempat ibadah ini. Semua umat Islam sepakat dengan fungsi masjid yang ini, namun kadang-kadang berbeda mengenai fungsi yang lainnya.

2. Masjid Sultan Riau Penyengat ini juga berperan sebagai lembaga dakwah, terbukti dengan adanya kegiatan-kegiatan untuk mensyiarkan Islam dan membangkitkan semangat beribadah, yang berupa kegiatan pengajian akbar, tilawah al-Qur'an dan sebagainya, walaupun tidak berfungsi sebagai masjid yang berpersantren. 
Peran masjid Sultan Riau Penyengat sebagai lembaga kemasyarakatan ada yang sudah termasuk ke dalam peran masjid sebagai lembaga ibadah, yaitu ketika shalat berjamaah. Ada juga yang melalui kegiatan keagamaan tertentu, seperti halnya tilawah al-Qur'an, pengajian, dan lain-lain. Masyarakat semua berperan aktif dalam hal itu.

\section{Referensi}

Al-Abrasy, Mohd Athiyah, Dasar-Dasar Pokok Pendidikan Islam, terj. Bustami A.Ghani dan Djohar Bahry, Jakarta: Bulan Bintang, 1970.

Amin, M. Darori, (ed), Islam dan Kebudayaan Jawa, Yogyakarta: Gama Media, Cetakan I, 2000.

Arifin, HM., Kapita Selekta Pendidikan (Umum dan Agama), Semarang: CV. Toha Putra, 1986.

Arifin, M., Filsafat Pendidikan Islam, Jakarta: Bumi Aksara, 1996

Arikunto, Suharsimi, Prosedur Penelitian: Suatu Pendekatan Praktik, Jakarta:Rineka Cipta, 2006.

Baqi, Muhammad Fuad Abdul, Al-Lu'Lu'Wal Marjan: Himpunan Hadits Shahih yang Disepakati oleh Bukhari dan Muslim, Jilid I, ter. Abdul Hayyie al-Kattani, ed. Darmadi, Jakarta: Gema Insani Press, Cetakan I, 2000.

Bogdan, Robert C, Sari Knop Biklen, Qualitative Research For Education: an introduction to theory and methods ,London: Boston London, 1982.

Dalimunthe, Fakhrur Rozy, Sejarah pendidikan Islam: Latar Belakang, Analisis dan pemikirannya, Medan: Rimbow, Cetakan I, 1986.

Darajat, Zakiyah, Ilmu Pendidikan Islam, Jakarta: Bumi Aksara, 1992.

Dhofier, Zamakhsari, Tradisi Pesantren: Studi tentang Pandangan Hidup Kyai, Jakarta: LP3ES, Cetakan VI, 1994.

Fadjar, A. Malik, "Pendahuluan: Strategi Pengembangan Pendidikan Islam Dalam Era Globalisasi", dalam M. Zainuddin dan Muhammad In'am Esha (eds), Horison Baru Pengembangan Pendidikan Islam Upaya Merespon Dinamika Masyarakat Global, Yokyakarta: Aditya Media Yokyakarta Bekerjasama dengan UIN Press, 2004.

Furchan, Arif, PengantarMetode Penelitian Kualitatif, Surabaya: Usaha Nasional, 1992.

Gazalba, Sidi, Mesjid Pusat Ibadah dan Kebudayaan Islam, Jakarta: Pustaka Al-Husna, Cetakan V, 1989.

Geertsz, Clifford, Abangan dan Santri Priyayi, ter. Aswab Mahasin, Jakarta: Pustaka Jaya, Cetakan III, 1989.

Hadi, Sutrisno, Metodologi Research Jilid I, Yogyakarta: Andi Offset, 1993.

Haji, Haris Daryono Ali, Dari Majapabit Menuju Pondok Pesantren: Santri-Santri Negarawan Majapabit sebelum Walisongo dan Babad Pondok Tegalsari, Tulungagung: Surya Alam Mandiri, 2009.

Hamim, Toha, Naif: Masjid Jadi Pusat pendidikan, Gerbang Edisi 06, No. 03, Pebruari-April 2000.

Harahap, Sofyan Safri, Managemen Masjid: Suatu Pendekatan Teoritis dan Organisatoris, Yogyakarta: Dana Bakti Wakaf, Cetakan I, 1993.

Hs, Fachrudin, Eksiklopedia Al-Qur'an, Jilid II, Jakarta: Rineka Cipta, Cetakan I, 1992.

Jabali, Fuad, Jamhari, IAIN dan Modernisasi Islam di Indonesia Jakarta : Logos Wacana Ilmu, 2002.

Marzuki, Metodologi Riset, Yogyakarta: BPFE UII Yogyakarta, 2001.

Mikel, Huberman A. \& Miles M.B, Qualitative Data Analisis, Beverly Hills: SAGE Publication, Inc, 1992.

Moleong, Lexy J., Metodologi Penelitian Kualitatif, Bandung: Remaja Rosda Karya, 2002.

Mulkhan, Abdul Munir, Khutbah-Khutbah Islam, Yogyakarta: Sipress, Cetakan I, 1992. 
Munawwir, Ahmad Warson, Kamus al Munawnir: Arab-Indonesia Terlengkap, Surabaya: Pustaka Progresif, 2002.

Nazir, Moh., Metodologi Penelitian, Jakarta: Ghalia Indonesia, 1988.

Qomar, Mujamil, "Perencanaan: Suatu Proses yang Terabaikan dalam Sistem Pendidikan Islam", Majalab Tarbiyab Tulungagung IAIN Sunan Ampel, no.9, Tahun V, 1993.

Qomar, Mujamil, Manajemen Pendidikan Islam, Jakarta: Erlangga, 2008.

Al-Qardhawi, Yusuf, Tuntunan Membangun Masjid, ter. Abdul Hayyie al-Kattani, ed. Darmadi, Jakarta: Gema Insani Press, Cetakan I, 2000.

Rahim, Husni, Arah Baru Pendidikan Islam di Indonesia, Jakarta: PT. Logos Wacana Ilmu, 2001

Rosyadi, Khoiron, Pendidikan Profetik, Yogyakarta: Pustaka Pelajar, 2004.

Siddiqi, Amir Hasan, Studies in Islamic History: Edisi Indonesia, ter. HMJ Irawan, Bandung: Al-Ma'arif, 1987.

Strauss, Anselm, Juliet Corbin, Dasar-Dasar Penelitian Kualitatif: Tatalangkah dan Teknik-teknik Teoritisasi Data, terj. Muhammad Shodiq dkek, Yogyakarta: Pustaka Pelajar, 2003.

Supeno, Wahyudin, Perpustakaan Masjid, Pembinaan dan Pengembangannya,ed. Abdul Hamid, Bandung: Remaja Rosdakarya, Cetakan I, 1984.

Woodward, Mark R., Islam Jawa: Kesalehan Normatif Versus Kebatinan, ter. Hairus Salim HS, Yogyakarta: LKIS, Cetakan I, 1999.

Yatim, Badri, Hafiz Anshori, Sejarah Peradaban Islam, Jakarta: Raja Grafindo Persada, Cetakan XI, 2000. 